Monsuru Olalekan Muritala

Senior Lecturer,

Department of History, University of Ibadan, Email: murimonsour@ gmail.com

DOI: https://dx.doi. org/10.18820/24150509/

SJCH44.v2.5

ISSN 0258-2422 (Print) ISSN 2415-0509 (Online)

Southern Journal for Contemporary History 2019 44(2):96-113

(C) Creative Commons With Attribution (CC-BY)

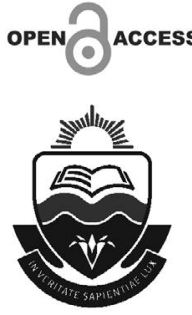

\section{THE SECOND WORLD WAR, TAXATION AND THE FAILURE OF COMMUNITY IN COLONIAL ILESA METROPOLIS, WESTERN NIGERIA}

\begin{abstract}
This research explores the nexus between the Second World War (World War II) and the episode of communal riots that broke out in Ilesa, Western Nigeria in 1941. Ilesa a town populated by the ljesa, a sub-group of the Yoruba was an extremely vibrant town during the colonial period. It provided opportunities in commerce and industry for both local inhabitants and settlers. However, in 1941, in the face of dwindling resources and acute competition occasioned by the World War II, the ljesa people descended on the visitors and settlers in their midst. This work, using undocumented oral reconstruction of popular memory in llesa and other parts of Western Nigeria, private papers, newspaper accounts and colonial official reports in the National Archives at Ibadan, National Archives in London and secondary sources provides extensive interpretation of the consequences of World War II on identity and intergroup relations in an urban milieu in colonial Nigeria.
\end{abstract}

Key words: Ilesa, Western Nigeria, Riot, Second World War

\section{INTRODUCTION}

"We are the children of Oduduwa" is a cherished cliché associated with the Yoruba of western Nigeria. Yet, the ljesa Yoruba attacked their kins and compatriots from other Yoruba sub groups in the 1940s. This work attempts a complex examination of the cultural and social politics that took shape in twentieth century llesa, Nigeria focusing on the highly combustible ljalgbooro episode of 1941 and its aftermath. The seismic changes that took place in ljesa social attitudes during the 1940s 
when upheavals and convulsions wracked the fabric of ljesa society can only be described as "revolutionary". This is because a group of ljesa irredentists sprang to life and whipped the society into a turmoil that ultimately had significant implications for inter-group relations in colonial Yorubaland. The social codes spurred on by group identity as children of Oduduwa, the ancestor of the Yoruba of Western Nigeria amounted to a major transformation of the social space. ${ }^{1}$

llesa is a principal town of the ljesa people, one of the sub groups of the Yoruba people. Yorubaland in the popular colonial classifications is populated by the Egbado and Awori of the llaro division of Abeokuta province; the Egba of Abeokuta Province; the various groups of ljebu in ljebu Province; the Oyo and Ilorin Provinces; the Ife and ljesa of Oyo Province, the Ondo Province, the Idoko, Ikale and Ilaje Ondo Province; the various small groups of related people known as the Ekiti, and Yagba, Igbomina of llorin and Kabba Provinces. ${ }^{2}$ All these people speak a language known as Yoruba, which belong to the Sudanic language family; it should also be pointed out that all the people are united in claiming lleIfe as their place of origin. ${ }^{3}$ They are further united in all claiming descent from a common ancestor Oduduwa of Ile-Ife. ${ }^{4}$

llesa has no doubt enjoyed scholarly attention but one of the outstanding literature in this regard has been that of the British Sociologist John.D.Y Peel, who has done a comprehensive narrative of this well-known Yoruba town, llesa. In his book, ljeshas and Nigerians: The Incorporation of a Yoruba Kingdom, 1880s-1970s, Peel made a copious reference to the llesa riot of $1941 .{ }^{5}$ Despite his narrative of the course and causes of the riot, he hinged the outbreak of the riot on ethnic cum cultural nationalism, especially the need for a socio-cultural group Egbe Omo Ibile ljesa (Association of ljesa Indigenes) to assert its independence and populate the Native Administration with ljesa local inhabitants. Though his sociological interpretation of the riot is excellent given his professional background, it largely ignored the global connection and the economic factors that precipitated the outbreak of the riot. Peel's approach reinforces the position of Aidan Campbell who opined that more and more academic fields are coming around to rely on ethnicity to provide their underlying explanation of human behaviour. ${ }^{6}$ It is on this premise that I argue in this paper that beyond ethnicity,

1 The Yoruba believe Oduduwa is the Father of the Yorubas and progenitor of all Yoruba Obas and the Oba of Benin. His sons founded the first sixteen Kingdoms of the Yoruba.

NA Fadipe, The Sociology of the Yoruba (Ibadan: Ibadan University Press, 1970), pp. 29-32.

Fadipe, The Sociology of the Yoruba, p.30.

Fadipe, The Sociology of the Yoruba, p.30.

JDY Peel, The ljeshas and Nigerians: The Incorporation of a Yoruba Kingdom, 1890s-1970s (Cambridge: Cambridge: University Press, 1983), p.191.

6 A Campbell, Western Primitivism: African Ethnicity, A Study in Cultural Relations (London: Cassell Wellington House, 1997), p.4. 
there is a connection between the Second World War and the community failure recorded in llesa in 1941.

The emergence of economic and social divisions within the llesa community of Western Nigeria is used here to fashion an account of the dynamics of change in ljesa politics and society during the World War II. Ultimately, the changes are also used to explain the fracturing of the Yoruba identity that had cemented the unity of this social group before the outbreak of the war. The research seeks to explore the connection between the World War II and the fracturing of this monolithic identity that ultimately led to the outbreak of civil disturbances in Ilesa, Western Nigeria in 1941. It also aims to investigate the role of the economic depression, the win-the-war effort of the British, the weakness of the llesa kingship institution and the failure of the Native Administration on the outbreak of the 1941 riots in llesa and its aftermath.

Like every other community under colonial rule, the ljesa people had also been affected by the fallouts of the World War II. In the first two years of the war, the Native Administration was in a very bad state. The traditional ruler of the town, Owa Aromolaran I, was too old to play any effective part in the day to day administration of the town. There were no regular council meetings such that, the ordinary channels of conflict resolution and communication for the towns under the Native Authority had been blocked by long neglect.

Besides, World War II (1939-1945) created immense socio-economic problems at the local levels. It was a period when the colonial subjects were required to give their sweat and blood while the colonial state requisitioned supplies. Able bodied men were also being drafted into the army. This was in addition to the negative impact of existing global depression that preceded World War II. The mobilisation of communities to provide labour, food and other resources for the war exacerbated some of the contradictions of colonialism, thus making World War II an equally significant watershed in African History. ${ }^{7}$ Colonial regimes faced rising tensions as some communities experienced food shortages in the wake of the redeployment of agricultural labour or the redirection of food to troops. ${ }^{8}$ Price controls on food, as well as restrictions on shipping and the movement of imported goods such as kerosene, helped fuel hyperinflation, especially in urban centres. ${ }^{9}$ The capacity of the people for capital accumulation dwindled significantly. Besides, it was a period when control was paramount, colonial officials had to devise new strategies and policies to secure the resources necessary for the war while keeping the lid on social and economic unrest. ${ }^{10}$

$7 \quad$ A Judith Byfield, "Preface". In: A Judith Byfield et al. (eds.), Africa and World War II (New York: Cambridge University Press, 2015), p.25.

8 Byfield, "Preface", p. 25

9 Byfield, "Preface", p.25.

10 Byfield, "Preface", p.25. 
Even then, different spaces and circumstances conferred different privileges and opportunities upon individuals and groups. The struggles within this globalised space seemed to have favoured non-residents in llesa."

The questions, however, are; How did the ljesa people of llesha react to this phenomenon? How did the ljesas begin to formulate difference and dispossession? What was the nexus of the riot and payment of taxes? What roles did the Egbe Omo Ibile ljesa play in the move against the non-ljesa in the Native administration? What roles did the Chattered Accounting Firms of Castleton Elliot and Adebayo Firms play in the outbreak of the riot? What does this case tell us about the dynamics of change in Africa during World War II? This is historical and contextual, aiming to situate civil disturbance in Ilesha within Nigeria's social, cultural and economic history on the one hand, and the global incident of the World War II on the other.

\section{THE SECOND WORLD WAR AND THE BACKGROUND TO ILESA RIOTS}

The World War II had a tremendous impact on all colonies. Although sub-Saharan Africa was spared, the fighting experienced by British colonies, North Africa and Asia, contributed substantially to the Allied war effort. ${ }^{12}$ This included bulk deliveries of cash crops, forced growing of raw materials, conscription for military service and domestic labour, and a severe curtailment of imports. ${ }^{13}$ However, beyond the labour, primary resources and military service of Africans, the people of Nigeria and Sub-Saharan Africa contributed funds largely generated from individuals, revenues and taxes of the various Native Administrations. A vivid confirmation of such remittances and generous donations to the war effort was expressed by Lord Beaverbrook:

Our debt of gratitude to the people of Nigeria and to the Nigerian Daily Times is increased by the further contribution received from your "win the war fund". Your colony stands proudly forth as a champion against the evil forces of oppression and by its self-sacrificing generosity and devotion to the Empire's cause is playing a noble part in the victory that will be ours. To all who subscribed to this latest contribution our thanks go forth in full measure. ${ }^{14}$

11 Interview: Author with I Fatiregun, Irojo quarters, Irojo, Ilesa, 17 September, 2017.

12 TOberst, "Transport Workers Strikes and the "Imperial Response": Africa and the Post-World War II Conjuncture", African Studies Review 31 (1), 1998, p.119.

13 Oberst, "Transport Workers Strikes", p.119.

14 The National Archives (TNA; Kew), Lord Beaverbrook papers PRO/ CO 323/1809/16, Lord Beaverbrook - Governor of Nigeria 14 January, 1941 (telegram). 
The above expression was a sincere acknowledgement of the sacrifice and generous donations from the people of Nigeria. It is important to state that between the months of July and December 1940, Nigeria had contributed a sum of $£ 40000$ into the "win the war fund". ${ }^{15}$ And in a similar show of appreciation, the Governor of Nigeria received a telegram from the home Government, which stated the following:

The amount subscribed is now sufficient to provide a bomber aircraft and the Ministry of Aircraft production would prefer so to use the money. I presume that this arrangement would be acceptable and that the single aircraft should be called NIGERIA. ${ }^{16}$

The Nigerian Daily Times was a prime partner in the campaign for donations. Besides, the support enjoyed by Britain in the colony extended to the Nigerian Taxpayers Association, which unanimously adopted a resolution after its meeting of $8^{\text {th }}$ March, 1940 that:

This meeting affirms its loyalty to the Commonwealth of the British Empire and pledges itself to make any sacrifice of life, limb or money that may be necessary for prosecuting the war to a great and victorious end". ${ }^{17}$

The loyalty of the good people of Nigeria had for Britain was vividly expressed by the Sultan of Sokoto Caliphate, who succinctly stated thus:

I wish to inform you that we heard recently that German wireless has said, "slaves driven natives of the English Colonies are compelled by force to contribute to the "win the war fund". This spontaneous contribution from the people of Sokoto Emirate is a token of their loyal prayers for victory. We hope that it will be possible to buy a fighter aeroplane with this money and that it may be called "Sokoto" so that it becomes our representative in defending the United Kingdom and in fighting the Empire's enemies. ${ }^{18}$

Arising from the above references, I argue that the response to the financial demands of the war period from colonies, especially Nigeria involved not only the government revenues, but also "voluntary" donations by the rich and the poor, civil servants and ordinary people as well as revenues from taxes. Nigerians for

15 TNA, Lord Beaverbrook papers PRO/CO 323/1809/16, Telegram exchanges between Lord Beaverbrook and Governor of Nigeria between July 1940 and 4 December, 1940.

16 TNA, Lord Beaverbrook papers PRO/CO323/Telegram no1095 between Lord Beaverbrook and the Governor of Nigeria on contributions to the "win the war" fund.

17 TNA, J.G Foley correspondence PRO/ CO/583/253/8, Colonel J.G. Foley, "Nigerian Taxpayers Seeking Light", Nigerian Taxpayers Association, 1940, p.4.

18 TNA, PRO/CO323 Telegram no1320 between the Sultan of Sokoto and the Governor of Nigeria, July 1940. 
example, contributed £210 999 to the war effort through the Nigeria war relief fund. ${ }^{19}$ During the period, there was zero tolerance for tax default. In addition the Great Depression, which preceded the war compounded the situation and elicited war induced inflation. This phenomenon, being global in scope, engulfed Africa during and following the World War II. Its causes consisted of the reduction of colonial imports supply, the relative price increase of those imports and the colonial policy of paying for government expenditure by increasing the amount of currency in circulation. Unfortunately, wages did not keep step with the rise in prices, while the consequent cost of living increased. ${ }^{20}$ Nevertheless, there was a strong connection between these global events and the civil disturbance that engulfed llesa, a metropolis in Western Nigeria during the war period.

\section{PRELUDE TO THE ILESA RIOT: THE NATIVE ADMINISTRATION DIMENSION}

On 6 January, 1941, llesa experienced a serious civil disturbance locally known as ljalgbooro (communal riot). The immediate cause of the riot was a violent altercation between Fadugba, a prominent chief of the town and the chief tax assessment officer, Lejoka Abiola. Chief Fadugba was called to the tax office at the instance of a household head who had been fined for not paying his tax as assessed. ${ }^{21}$ This was part of the immediate cause of the riot, which wreaked havoc on the town in forms of arson, wanton destruction of property, harassment of settlers and occupants, and eventual trial and imprisonments of suspected culprits.

The build up to this riot started with the dissatisfaction of the educated elites with the performance of the Native Administration in llesa under the headship of the Owa Aromolaran I. It is widely accepted that indigenous political structures and the meaning of tradition were essential factors in the British colonial strategies of administration in Africa. ${ }^{22}$ Olufemi Vaughan argues further that, the questions of local governance were shaped by the shifting meaning of traditional political authorities, the perspectives of British administrators,

19 G Chuku, "Crack Kernels, Crack Hitler: Export Production Drive and Igbo Women during the Second World War". In: JA Byfield (eta al) (eds.), Gendering the African Diaspora: Women, Culture and Historical Change in the Caribbean and Nigerian Hinterland (Bloomington: Indiana University Press, 2010); J A Byfield, "Preface". In: J A Byfield (et al) (eds.), Africa and World War Il (New York: Cambridge University Press, 2015), p.25.

20 Oberst, "Transport Workers Strikes", p. 120.

21 JDY Peel, The ljeshas and Nigerians: The Incorporation of a Yoruba Kingdom, 1890s-1970s (Cambridge: Cambridge: University Press, 1983), p.191.

220 Vaughan, "Chieftaincy Politics and Communal Identity in Western Nigeria, 1893 -1951", The Journal of African History 44(2), 2003, p.283. 
prevailing colonial imperatives, the role of local elites and the rapidly changing social conditions of colonial jurisdiction. As emerging colonial rules transformed the meaning of traditional authorities, they encouraged recurring controversies among traditional and modern elites who claimed to represent competing local constituencies. ${ }^{23}$ Nnamdi Azikiwe, a foremost Nigerian nationalist, reinforced this position when he complained that Native Administrations were based on the premise that autocracy was the typical Nigerian political institution. According to Azikiwe, this was all very well for parts of Northern Nigeria, but not for the South, which possessed highly democratic instincts; therefore he considered Native Administration a major mistake. ${ }^{24}$ These assertions by Vaughan and Azikiwe best describe the situations in llesha in the 1940s.

The Native Administration structure derived from the British general structure of indirect rule. In llesa and some other important towns in Western Nigeria, the chiefs were gazetted as the Sole Native Authorities. However, the actual form of rule was that of Chief-in-Council. As a rule, the councils consisted of title-holders, most of them had qualified for this position by passing through grades of the title societies which formed so noticeable a feature in the life of this part of Africa. ${ }^{25}$ Promotion through these grades is partly hereditary and partly by selection. The societies have, by tradition, a definite function with regard to the regulation of court ceremonial or public affairs, and their members, as a whole, the guilds or other groups into which the working classes formed themselves. As a result, the councils normally consisted of older men, with little education; as such one of the outstanding problems of Yorubaland administration arose from the movement for securing representation of the less "aristocratic" elements in the community on the councils. ${ }^{26}$ The driving force behind this movement was the Nigerian Youth Movement (NYM), which had a membership of 10 000, out of which about three-quarter was derived from various parts of Yorubaland. ${ }^{27}$ The Motor Union with over 2000 members and the Producer's union also played a prominent part in the movements and there were local associations who plugged into the movements agenda by localising the politics. In llesa, two such prominent associations were the Egbe Atulunshe (The Young ljesa improvement Union) and The Egbe Omo Ibile ljesa (Association of ljesa indigenes).

The Native Administration in llesa had been under criticisms by Egbe Atunlushe and the Nigerian Youth Movement. As early as 1939 when a letter was

Vaughan, "Chieftaincy Politics", p. 283.

TNA, PRO/CO 583/253/1. Dr Nnamdi Azikiwe- A.J.Loch, on the future political development of Nigeria, 30 October 1940 (correspondence).

TNA, PRO/CO 847/22/9, "Native Administration: Comparative Survey: Nigeria".

TNA, Lord Hailey papers PRO/CO 847/22/9, Lord Hailey on the Native administration in Nigeria in the 1940s, June 1940, p. 2.

TNA, Lord Hailey papers PRO/CO 847/22/9, Lord Hailey on the Native administration in Nigeria in the 1940s, June 1940, p. 2. 
written to the Owa Aromolaran-the monarch, advising that llesa judicial and fiscal incompetence might be better rectified if a non-resident of the town was to be appointed as council clerk. ${ }^{28}$ The Owa responded by appointing his literate nephew Adesuyi. This did not still satisfy members of the NYM and the Egbe Atunlushe. In fact, Peel posited that, the resentment at the employment of nonljesa began to reverberate more widely around the town and got compounded with other grievances. The catalyst was thus provided by a handful of literate men, some of them former government clerks, who had retired from service outside ljesaland. ${ }^{29}$ The resentment against the non- residents such as Mr. Ige, who hailed from Ibadan and headed the treasury section of the llesha Native Administration, climaxed in May 1940, when a retired civil servant J.B. Akinola of ljoka quarters wrote a letter to the Assistant District Officer (ADO) demanding the need to employ non- residents in the "Native" Authority. The most important aspect of his letter reads, "It is easier for an aborigine to know the dealings, feelings and interest of his people than a mere stranger who comes for his daily bread and pocket". ${ }^{30}$ All the highest NA positions at Ilesa, he claimed, were held by non- residents, though in other places like Ife preference was given to the local people. ${ }^{31}$ Getting no satisfaction from these letters and series of interviews held with the chiefs, the educated elites in the NYM and Egbe Atunlushe consulted J.S. Oginni, Chairman of EgbeAtunlushe, who advised them to form a society. ${ }^{32}$ By mid-July, 1940 Egbe Omo Ibile ljesa (The Society of Native ljesa Sons) came into being..$^{33}$

The Egbe Omo Ibile ljesa at the outset was loosely organised around a core of founder members, who did not establish a hierarchy of offices but all contributed to the agitation work of writing letters to officials, writing petitions and spreading the word among the population. There was no membership list, since all ljesa were considered members of the society. To the foregoing, founders were soon added Richard Ogedengbe and J. A.Fadugba from the NYM, and it was Fadugba who soon came most to embody the Egbe Omo Ibile ljesa the most in the Public eye.

Before the riot, Fadugba was not in good books with District Officer and the police because he was known to have been a bankrupt produce buyer indebted to the tune of $€ 300$. Besides, he was said to have previously assaulted Mr. Cardale-

28 Fadugba Private papers, Nigerian Youth Movements (NYM) letter to Owa, Aromolaran 1, 20 April 1939, Obafemi Awolowo University, lle-Ife, Nigeria.

29 Peel, The ljeshas and Nigerians, p.186.

30 Fadugba Private papers, J B Akinola in a correspondence to the Assistant District Officer (ADO), 3 May, 1940 Obafemi Awolowo University, lle-Ife.

31 Fadugba Private papers, J B Akinola in a correspondence to the Assistant District Officer (ADO).

32 Peel, The ljeshas and Nigerians, p.186.

33 Peel, The ljeshas and Nigerians, p.186. 
theAssistant District Officer. ${ }^{34}$ In spite of this, however, Fadugba led 12 committee members in a petition against the Native Administration in llesa. They alleged many grievances against the Native Administration the principal being the misappropriation of NA funds by the Owa of llesa and his chiefs. For clarity, the summary of the allegations are as follows:

I. The Owa was not really accessible to his people. He encouraged them to contribute to his expenses for the Western Provinces Chiefs' conference. He was not sufficiently generous. He did not give the youth of the town opportunities to express themselves on Public affairs. His failings however, were due to bad advisers rather than to faults of his own.

II. The personal rivalry and jealousy between Chief Lejoka and Chief. Fadugba

III. The demand that the posts of Treasurer and Senior Native Court Clerk should be held by ljesas. That the Treasurer, besides his treasury duties, was a personal clerk, interpreter and adviser to the Owa. He was paymaster to the Public Works Department and being in league with an African Overseer, they drew money for labourers who did not exist. That when ljesa had boundary disputes with neighbouring peoples, for example Ife and Ede. The treasurer, being a non- resident gave away information to the other side.

IV. Suspicion of the Reformed Ogboni Fraternity owing to the secrecy which surrounds its activities. Its membership was said to include most of the Native Administration staff and its influence in official circles made any reform impossible. Members of the fraternity were suspected of obtaining loans from the Public funds in the custody of the Treasurer. Sawyers who were members of the Ogboni were able to fall trees without taking out permits.

V. The tax in the town should be collected by the heads of quarters who should receive $10 \%$ of the amount collected. The time limit given for payment of tax was too short; fines were too heavy and members of theEgbe Omo-Ibile ljesa were singled out for punishment.

VI. In the Native Court the price of justice was too high. Some fines were never paid into the treasury and people who had been fined $€ 3$ were given a receipt for only $12 / 6$. Women who were granted divorce were not made to refund dowry. The Senior Court Clerk was clerk to the appeal court as well as clerk in the lower courts (criminal and civil). Members of the lower courts also sat as judges on the appeal court.

$34 \quad$ National Archives Ibadan, Oyo Prof, file no 547/17, Investigation report on llesha Riot, submitted by the Superintendent of Police, OYO-Ondo Province to the Commissioner, the Nigeria police Headquarters in Lagos, $11^{\text {th }}$ January, 1941. 
VII. Appointments to vacancies in the Native Administration were governed by favouritism

VIII. An intelligence report was overdue..$^{35}$

Consequently upon these allegations, the society approached the Resident Officer and requested permission for an independent audit of the NA accounts. Permission was granted and in due course an audit report was prepared by Adebayo Audit Firm in Lagos. In addition to the prior, the society demanded the removal of all non-ljesa from official positions in the Native Administration and in support of their wishes, advanced allegations of malpractice against Ige, the Treasurer of the Native Administration. This official was a resident of Ibadan and had spent 27 years in service with the llesa Native Administration. In this removal demand, Chiefs Loro and Lejoka were not spared.

It is important to state that at the time of the outbreak of the riot, the audit report of Adebayo Accounting firm had not reached the Resident Officer. In consequence, the action of the rioters was considered as premature by the Resident Officer without knowing that Fadugba and others who instigated them had gotten information from the Adebayo audit firm before declaration of the audit report. ${ }^{36}$ The question at this point may then be asked, what is the connection of the riot with the World War II?

\section{WORLD WAR II AND ILESA ZERO TOLERANCE POLICY ON TAX PAYMENT}

British colonial tax policy according to Abiodun Afolabi, brought about unlimited exploitation and expropriation of capital from the periphery to the metropolis as well as other changes and development in the south-west region of Nigeria. ${ }^{37}$ This was not limited to the south-west of Nigeria but the entire colonial Nigeria. The exploitation associated with this tax regime generated reactions throughout Nigeria. One of the most studied incidents of protest against colonial taxation in Nigeria is that of Aba Women Riot of 1929. Koko Ete Ina argues that, the tax crisis of 1929 was significant because it brought about the end of the Warrant Chiefs system and the inauguration of another phase of indirect rule, the Native Authority System in the south-east region under colonial rule. ${ }^{38}$ This attest to the fact that, the llesa riot against Native Administration was not the first of its kind

35 National Archives Ibadan, Oyo Prof file no 3065/59, correspondence from H.F.M. White, Resident Oyo Province to the secretary, western provinces, Ibadan on the llesha Riot, 6 February, 1941.

36 Fadugba private papers, Obafemi Awolowo University, lle-Ife, Nigeria.

37 A Afolabi, "The colonial taxation policy and Yoruba of the south-west Nigeria and its implication for socio-economic development", Journal of the Historical Society of Nigeria 19, 2010, pp.63-92. K Ete Ina, "The tax Crisis of 1929 in Ibibioland", Transafrican Journal of History 21, 1992, pp. 171-181. 
in Nigeria, but its uniqueness lie in the fact that it was a local crisis which had connections with global event- the World War II.

Following the outbreak of the World War II and the inauguration of the Win-the-war Fund, Ilesa Native Administration was accused of poor performance in tax collection and revenue remittance. ${ }^{39}$ The Owa in Council sought the permission of the District Officer to institute prosecution for failure to pay tax and this was granted by the District Officer in good faith. Subsequently, the issuing of summons was left to the Council. In the view of H.F.M White the Resident Officer, Oyo Province, the Owa and his Chiefs abused the prosecution privilege granted to them. In fact, between 24 December 1940 and 4 January 1941, a total of 137 summonses had been issued against compound heads in llesa. ${ }^{40}$ One of residents in llesa indeed confirmed that tax evasion by llesa residents served as a form of subtle protest by ljesa people to register their dissatisfaction with the Native Administration tax regime in ljesaland. ${ }^{41}$ In addition to summons, the numbers of cases which came before the court and on which fines were imposed were as follows:

Seven cases on the 30 December, 1940

Five cases on 31 December, 1940

Ten cases on 2 January, 1941

Eleven cases on 3 January, 1941

Five cases on 4 January, 1941

Nine cases on the 6 January, 1941

The addition of all cases before the court by the eve of the riot was 47 in number. ${ }^{42}$ These were considered outrageous by the Resident Officer, Oyo province. The outbreak of the riot indeed confirmed the peak of discontentment and anger on the part of the citizenry, especially the Egbe Omo Ibile ljesa.

\section{ILESA RIOT AND ITS AFTERMATH}

By December 1940, the Native Administration was still not satisfied with the pace of tax payment and as such intensified legal action to enforce payment. The climax can be said to have been reached on the afternoon of the 6 January, 1941, when Fadugba made it his business to go to the Tax office to protect tax defaulters. An altercation ensued between Fadugba and the Chief Tax Assessment Officer, Lejoka Abiola in the presence of other chiefs. Attempts were

39 National Archives Ibadan, Oyo Prof, file, 3065, Volume II, Tax payment in llesha, 16 January 1941.

40 National Archives Ibadani, Oyo Prof 1, file 3065/29, Correspondence between H.F.M Whiteresident Oyo province and the secretary, Western Province, Ibadan, $16^{\text {th }}$ January, 1941.

41 Interview: Author with I Fatiregun, Irojo quarters, Irojo llesa, 17 September, 2017.

42 National Archive Ibadan, Oyo Prof, file no 3065/29; see correspondence between the ResidentOyo Province and the Secretary, western provinces on Riots in llesha, 16 January, 1941. 
made to arrest Fadugba but a scuffle broke out among the people in the office and Fadugba left for Ademilola's house near Ereja, where he was arrested. ${ }^{43}$ His arrest sparked off reactions. Shortly afterwards, the compound was filled with a mob of about 3000 people in a state of anger giving expression to their grievances.

This mob, which appeared to consist of the younger elements of the town, was armed with machetes, guns, sticks and clubs. The District Officer was informed in faraway lle-Ife, and he quickly ordered the police to give a quick response in an endeavour to check the ensuing assault. ${ }^{44}$ The intervention of the District Officer yielded result as order was restored by $10.30 \mathrm{am}$. By this time Fadugba had been released from the Native Administration prison. This apparently encouraged the crowd to re-strategise and launched another protracted attack which started around 7 o'clock in the evening and lasted till 3 o'clock the following morning.

By the day break of the 7 January, 1941 the riot continued again and eventually drew people of the adjoining villages to join in the riots. The rioters attacked the Native Administration tax offices and the clerks were driven out by stoning. The prison was visited and the prisoners were released. The Native Administration's Treasurer's house was badly damaged. Besides destroying the meeting houses of the Reformed Ogboni Fraternity by setting it ablaze, they also damaged the houses of the following people: Chief Adeniran (son of the Owa), Chiefs Loro, Lejoka (two houses), Longe and Farinmade. Obad are Owopetu, for instance, while narrating the extent of the riot in his account opined that the furious mob moved round the town to wreak havoc on the ordinary citizens, destroying and looting property of businessmen and non-residents in a warlike mood. He said, it was their war songs that alerted them in his household. The rioters were violent and sang as follows; Akadigbomooriigiodigbo, awo bi eiyetimaafo, odigbo (The big bird has been cornered on its nest; there is no escape means for the bird) 45 lyaolomo de omo re mokokoaomabaooo (caring mother has shielded her child from attack, he has fled). ${ }^{46}$

The first song was on the lips of the rioters when approaching the house of a target of attack. If the target was at home, the attack would be carried out. If the target was not at home, the song would change to the second one to express their disappointment. The violent nature of the mob was corroborated by Idowu Fatiregun, an eye witness who confirmed that his household was attacked, and that it took his timely arrival and that of his father to save his step-mother from the crowd that had attacked her and dragging her on the floor. ${ }^{47}$ In another

\footnotetext{
43 Peel, The ljeshas and Nigerian, p.191

44 National Archive Ibadan, OYO Prof, file 3065, Riots in Ilesha, 1940 -1941, Volume 1.

45 Interview: Author with OE Owopetu.

46 Interview: Author with OE Owopetu.

47 Interview: Author with I Fatiregun, 86 years at Irojo quarters, Irojo Ilesha, 17 September, 2017.
} 
account Adelola Adeloye narrated that, the ljeshas who considered themselves as inveterate traders had been badly affected by the economic depression of the 1930s and the World War II. They thought that the settlers on their land were competing with them for the existing limited market in the city during that difficult period. During the rioting those who feared the animosity sparked off by economic depression left the city. Adelola Adeloye's father, Pa Adeloye; a top notch automobile technician in llesa but from Ekiti, his colleague, S.K. Momodu, also non-ljesa resident and lyagba from the Middle Belt of Nigeria, who also had his workshop at Otapete near the Methodist Church, relocated from Ilesa to their various ancestral towns and villages. ${ }^{48}$ Similarly, Olukunle Ifedayo buttressed the fact that the rate at which the rioters looted traders shop, especially those of Syrians resulted in the relocation of many of them to Ibadan during the period. According to him, this robbed him of his first job as a sales clerk to one of the Syrian traders. ${ }^{49}$

As observed by Peel, no serious injury or death was recorded during the riot. However, his position that the main allegation of the rioters was clearly against the powerful ljesa in the circle of privilege around Owa, rather than against the local people is contestable. I therefore argue that given the background to the riot in which letters emanated from prominent ljesa sons and daughters as represented by Egbe Omo Ibile ljesa, demanding at different occasions the replacement of all non-resident principal officers in Native Administration in llesa with ljesa local people and the attack carried out on non-ljesa traders and artisans attest to the fact that non-residents were the targets. In addition, eye witnesses' account as explained in the last paragraph above confirms that not only the nonresidents in Native Administration were affected but, traders, artisans, farmers and others with economic interest in the informal sector.

The aftermath of the riot was characterised by indiscriminate arrest of citizen by the police and counting of losses by those affected. For instance, the estimated costs of the properties damaged are highlighted in the Table 1 below:

48 A Adeloye, My Salad Days: the Primary School Years (Ibadan: Book Builders, 2009), p.8.

49 Interview: Author with O Ifedayo, Imo Area, Ilesha, 16 September 2017. 
Table 1:Highlight and Estimates of Damaged Property during the Riot

\begin{tabular}{|l|l|c|c|}
\hline S/N & \multicolumn{1}{|c|}{ Property Type } & Name of Owner & $\begin{array}{c}\text { Estimated Cost } \\
\text { of Damage }(£)\end{array}$ \\
\hline 1 & $\begin{array}{l}\text { An old Building of Mud Walls at } \\
\text { Odooro Quarters }\end{array}$ & Chief Loro & 101.1 .10 \\
\hline 2 & Reformed Ogboni Lodge & $\begin{array}{c}\text { Reformed Ogboni } \\
\text { Fraternity (ROF), llesha. }\end{array}$ & 195.7 \\
\hline 3 & Quality two storey building & Chief J.D. Abiola Lejoka & 104.12 \\
\hline 4 & $\begin{array}{l}\text { Window/front wall of a bungalow } \\
\text { belonging to native court judge, } \\
\text { Oshogbo }\end{array}$ & Mr.J.F. Longe & 3.15 \\
\hline 5 & $\begin{array}{l}\text { A very extensive and } \\
\text { exceptionally built property }\end{array}$ & Prince S.A. Adeniran & 308.14 .9 \\
\hline 6 & Official House but old property & Chief Lejoka & 167.2 .2 \\
\hline 7 & Private property of good quality & $\begin{array}{c}\text { Mr. S.B. Ige- Native } \\
\text { Administration Treasurer }\end{array}$ & 16.16 \\
\hline 8 & Ilesa Private Property & Mr Farinmade & 25.4 \\
\hline
\end{tabular}

Source: NAl, 3065/148, Memorandum from the Native Authority Works Department to the Senior Resident, Ibadan, 12May, 1941.

The above table shows the summary of the relative damage experienced by victims of the riots. After the arrest of suspected culprits in the riot, the trial started in Ibadan on 21 January, 1941. Quite a large number of eager spectators and llesa local people were present at the Magistrate Court when formal deposition began. Fadugba, the leader of the Egbe Omo ibile ljesa was charged with inciting people not to pay tax, behaving in a manner likely to cause breach of peace and escaping from lawful custody. ${ }^{50}$ Emmanuel Oke and Ademilola were charged with rescuing the accused; Fadugba from lawful custody. The other arrested suspects were not charged the first time but after series of court trials all of them including Fadugba were sentenced into imprisonment. The summary of their charges and sentences are highlighted in Table 2 as follows: 
Table 2: Schedule of Sentences

\begin{tabular}{|c|c|c|c|c|}
\hline $\mathrm{S} / \mathrm{N}$ & Name & Sentence & $\begin{array}{c}\text { Date of } \\
\text { Sentence }\end{array}$ & $\begin{array}{c}\text { Date Due for Discharge } \\
\text { under Marks System }\end{array}$ \\
\hline 1 & J.A. Fadugba & 9 months & 26.2 .41 & Already discharged \\
\hline 2 & Agboola Samuel & 3 months & 15.3 .41 & -do- \\
\hline 3 & Tudumusa Adeyeye & 3 months & 15.3 .41 & -do- \\
\hline 4 & Awe Amure & 1 year & 15.3 .41 & 14.11 .41 \\
\hline 5 & Gbabi Olorunkosi & 1 year & 15.3 .41 & -do- \\
\hline 6 & Ajayi & 1 year & " & -do- \\
\hline 7 & Samuel Agboola & 1 year & $"$ & -do- \\
\hline 8 & Adeoti Adewunmi & 1 year & $"$ & -do- \\
\hline 9 & Aluko Asha & 1 year & $"$ & -do- \\
\hline 10 & Giwa One & 1 year & " & -do- \\
\hline 11 & Gabriel Olaide & 1 year & " & -do- \\
\hline 12 & Fowowe Shasore & 1year & $"$ & -do- \\
\hline 13 & Michael Olowokere & 1 year & $"$ & -do- \\
\hline 14 & Christopher Risawe & 1 year & $"$ & -do- \\
\hline 15 & Adegboyejo Jegede & 1 year & " & -do- \\
\hline 16 & Ojo Latunji & 1 year & " & -do- \\
\hline 17 & Alo Alokosi & 1 year & $"$ & -do- \\
\hline 18 & S.A. Ademilola & 2 years & 25.2 .41 & $24^{\text {th }}$ June, 1942 \\
\hline 19 & J.B. Oni & 2 years & 28.2 .41 & $27^{\text {th }}$ June, 1942 \\
\hline 20 & Akinola & 2 years & 13.3 .41 & $12^{\text {th }}$ July, 1942 \\
\hline 21 & O.I. Alaye & 2 years & $"$ & -do- \\
\hline 22 & Eman Oke & $31 / 2$ years & 25.2 .41 & -do- \\
\hline 23 & Mathew Adedoyin & $31 / 2$ years & 27.2 .41 & -do- \\
\hline 24 & Jacob Jalugbo & $31 / 2$ years & 27.2 .41 & -do- \\
\hline 25 & Jegede Lemodu & $31 / 2$ years & " & -do- \\
\hline 26 & Benjamin Ajiloro & $31 / 2$ years & " & -do- \\
\hline 27 & Jejel sare & $31 / 2$ years & $"$ & -do- \\
\hline 28 & Risa ljoke & $31 / 2$ years & $"$ & -do- \\
\hline 29 & J.L. Ogedengbe & $31 / 2$ years & " & -do- \\
\hline 30 & M.A. Haastrup & $31 / 2$ years & " & -do- \\
\hline 31 & Josiah Apoesho & $31 / 2$ years & 11.3 .41 & 10 $0^{\text {th }}$ July, 1943 \\
\hline 32 & Titus Alo & $31 / 2$ years & 11.3 .41 & -do- \\
\hline 33 & Daniel Gidigbi & $31 / 2$ years & $"$ & -do- \\
\hline 34 & Gabriel Omole & $31 / 2$ years & $"$ & -do- \\
\hline
\end{tabular}

Source: Oyo Prof 2/1, "Riots in Ilesa" Volume II, Correspondence between J.A Mackenzie, Secretary, Western Provinces and the Chief Secretary to the Government, Lagos, 16 October, 1941. 
Following the imprisonments of the suspected masterminds of the riot, series of meetings were held between the colonial officials, the residents and all relevant stakeholders in order to bring peace back to the town. Colonial authorities first attended to claims for damages by those who suffered during the period of the riot, the number of which had increased when the dust settled. In a letter dated 11 February, 1941 written by Mr. H.F.M White, the Resident Officer of Oyo Province to the District Officer, llesa, he directed that a sum of $£ 2$ 659.7.9d should be paid as compensation to 87 affected residents of llesha town who suffered during the riot. ${ }^{51}$ Besides, there also emerged illuminating facts from the Adebayo Audit Firm, which had been leaked to Chief Fadugba and some members of the Egbe Omo Ibile ljesa before the outbreak of the riots about the gravity of allegations of bribery and corruption levelled against the Owa, the treasurer, members of the Native Administration and the reformed Ogboni fraternity. No doubt, this infuriated the Egbe Omo Ibile Ijesa leadership and eventually culminated in the outbreak of the riots. A summary from the audit report of Adebayo Firm is highlighted thus:

1. Some authorised payment were made by the Native Authority without the signature approval of the District Officer

2. Certain Salaries were recorded paid to chiefs but found not to have been paid. In addition, the sum of $£ 820.5$ - emoluments due to chiefs were kept in Deposit account

3. Evidence of duplication of contract and improper awarding of contracts by the Native Authority

4. Discovery of about 480 unauthorised payment vouchers and alleged corruption on the part of the Treasury under the leadership of one Mr lge, non-native of llesa

5. Diversion of 40 drums of cement meant for the construction of Oni River Bridge by Engineers in the Public Works Department of the Native Authority

6. Native Administration lost $£ 8000$ to illicit killing of cattle and felling of trees, especially by members of the Reformed Ogboni Fraternity in the Native Administration.

7. Allegation that Tax revenues counterfoils for the year 1939/40 were burnt by the Native Administration in order to conceal fraud perpetrated by the treasury headed by Mr. Ige.

51 National Archive Ibadan, Oyo Prof 3066/315, Correspondence between the Resident, Oyo Province and the District officer, llesha on "compensation for llesha riot victims", 11 February 1941. 
8. Accusation of the Native Administration of misappropriating $£ 5000$ on investment without concrete evidence to support or show for the investment

9. Accusation of Cassleton Elliot \& Co of preparing incorrect Balance Sheet in their audit report for the Native Administration.

A careful examination of the above audit report reveals that, the allegations apparently motivated the educated elites and the Egbe Omo Ibile ljesa to demand for the removal of Ige, a non-resident from the treasury as well as other Native administrators who had been perpetrating fraud with the finances of the town. This bottled up anger eventually exploded during the riot following a dispute over non-payment of taxes by house heads.

However, it is important to note that by the time Adebayo Audit Firm report came out officially, it generated reactions and was not taken as the true reflection of the state of affairs in the Native Administration. Rather Cassleton Elliot \& Co- the official audit firm of the Native Administration responded to all the allegations and refuted all the claims of the Adebayo Firm. In fact, Murphy, the representative of Casselton Elliot succinctly registered his disappointment in the Adebayo Firm audit report by arguing in defence of the criticisms levelled against Casselton Elliot Audit Firm. He submitted that Mr Adebayo has not been advised of the main principles of Native Administration Accounting. Therefore, his apparently technical arguments are futile, extremely misleading, and on the face of it, untruthful. ${ }^{52}$

The two accounting firms locked horns in accusations and counter accusations over professional competence, but the deed had been done. Riots, in which houses were burnt, valuables carted away, non- residents relocated and some serving jail terms in prisons had wracked the city.

\section{CONCLUSION}

This paper has investigated the remote and immediate causes of the llesa Riot of 1941 using both primary and secondary sources as well as undocumented memory to reconstruct the civil disturbance that bedevilled one of the most hospitable and peaceful towns in western Nigeria under colonial rule. I have been able to establish that, beyond ethnicity which appears to be the reason for the riot on the surface, the revenue drive associated with the mobilisation for the "Win the War Fund" at the global level elicited the drive at the local level for generation of more money in order for llesa to be self-sufficient financially, that is, without any recourse to the central authority for assistance to run the town. Instead, money was also mobilised at the local level for the war campaign of the British

52 National Archives Ibadan,Oyo Prof 3065, Mr. F.W. Murphy Report on Adebayo Firm Audit of llesha Native Administration Account, 6 February, 1941. 
colonial government. One of the measures adopted by the Native Administration in llesa was the zero tolerance on tax payment. This was grossly abused as many house heads were fined arbitrarily for non-payment of taxes. This process did not well with the highly disgruntled educated elites, the Egbe Omo Ibile ljesa and the residents of llesa. The climax of widespread discontentment led to the outbreak of riots between 6 January 1941 and 8 January, 1941.

\section{ACKNOWLEDGEMENTS}

This paper was completed while I was a British Academy Fellow at Queen Mary University of London in 2018. I am most grateful to the British Academy for granting me the fellowship and the fund, which enabled me to search for materials at the National Archives, Kew in London, and also at the British Library and other Libraries and research centres in London. My sincere appreciation to my host Dr. Leslie James and the entire faculty members of the School of History, Queen Mary University of London for their support and encouragement during the period of my fellowship. My sincere appreciation goes to the Centre for African Studies, University of Cambridge for granting me the opportunity to present this paper at one of their seminars. I also want to appreciate Professors Akanmu Adebayo and Olutayo Adesina for their useful comments while conducting the research as well as writing this paper. Finally, my appreciation goes to the management of the University of Ibadan, for granting me research leave during the period of my fellowship at Queen Mary University of London. 